\title{
Plasma glucagon levels in the term human infant and effect of hypoxia
}

\author{
D. I. JOHNSTON and S. R. BLOOM \\ From the Department of Child Health, King's College Hospital, Denmark Hill; and \\ the Institute of Clinical Research, Middlesex Hospital, London
}

\begin{abstract}
Johnston, D. I., and Bloom, S. R. (1973). Archives of Disease in Childhood, 48, 451. Plasma glucagon levels in the term human infant and effect of hypoxia. The mean plasma pancreatic glucagon level at birth in 44 normal infants delivered vaginally was $140 \mathrm{pg} / \mathrm{ml}$. The simultaneous maternal level was $122 \mathrm{pg} / \mathrm{ml}$ which was not quite significantly different at the $P<0.05$ level. 2 hours after birth 30 of these infants had a mean rise in plasma glucagon of $51 \mathrm{pg} / \mathrm{ml}(P>0.01)$, and their mothers had a fall of $38 \mathrm{pg} / \mathrm{ml}(\mathrm{P}>0.05)$. The mean plasma pancreatic glucagon level at birth in 12 normal infants delivered by caesarean section was $130 \mathrm{pg} / \mathrm{ml}$ which did not differ significantly from the group delivered vaginally. The glucagon level at birth in 20 infants with fetal distress (fetal scalp $p H<7.2$ or umbilical artery $p \mathrm{H}<7 \cdot 15)$ was $244 \mathrm{pg} / \mathrm{ml}$, and this was significantly higher than for normal infants at birth $(P>0.01)$. Whereas the rise in neonatal glucagon 2 hours after birth might have been caused by a mean fall in blood glucose of $23 \mathrm{mg} / 100 \mathrm{ml}$, the infants with fetal distress had normal glucose levels, so that another mechanism must be responsible for their raised glucagon.
\end{abstract}

The level of pancreatic glucagon at birth and the change that occurs in the first hours of life have not previously been reported. The adaptation of the human fetus to an independent existence requires mobilization of energy stores. The fetus accumulates a considerable reserve of hepatic glycogen in the latter part of gestation (Shelley, 1961) and this appears to be responsible for the maintenance of blood glucose after birth (Shelley and Neligan, 1966). Glucagon has been shown to activate hepatic glycogenolysis and gluconeogenesis (Park and Exton, 1972) and may play a significant role in energy homoeostasis of the newborn. Studies in the rat indicate that it may also induce the synthesis of certain rate-limiting enzymes in the gluconeogenic pathway (Philippidis and Ballard, 1970).

Liver glycogen is rapidly depleted when animals are exposed to acute anoxia (Mott, 1961). In the human it is not possible to measure hepatic glycogenolysis directly but the hypoxic fetus appears to raise its plasma glucose and lactate (Stembera and Hodr, 1966; Gennser and Nilsson, 1971), and it may be inferred that this is the result of the mobilization of liver glycogen.

Received 6 October 1972.
The two difficulties that have hitherto impeded the radioimmunoassay of human neonatal pancreatic glucagon are lack of sensitivity and cross-reaction with enteroglucogon, an immunologically similar hormone released from the small intestine. The raising of a highly avid and relatively specific antibody has sufficiently overcome these problems to permit glucagon assay even with the small plasma volumes which it is reasonable to obtain in human neonatal research.

\section{Patients and methods}

Fifty-six mothers and infants who had Apgar scores of 7 or above at 1 minute were studied. 44 were delivered vaginally and 12 by elective caesarian section, performed either because of pelvic disproportion or because of a previous caesarean section; there was no indication of fetal distress in this group. The majority of the mothers received intravenous infusions of glucose during labour. The mean infant birthweight was 3.4 kg (range 2.75 to 3.88 ) and all were appropriate for gestational age (Tanner and Thomson, 1970).

In a separate group of 20 infants labour was complicated by clinical signs of fetal distress-irregularities of the fetal heart or release of meconium. The management of these cases followed the scheme described by Beard et al. (1971) in which the fetal condition was monitored by fetal scalp $p \mathrm{H}$ measurement and conti- 
nuous fetal heart rate recording. In all these 20 cases fetal acidosis was shown (fetal scalp $p H<7 \cdot 20$ and/or umbilical artery $p H<7 \cdot 15)$ and was an indication for forceps extraction in 8 , and emergency caesarean section in 12. 17 of the infants had an Apgar score of less than 7 at 1 minute. The mean birthweight (range) of this group was $3 \cdot 0 \mathrm{~kg}(2 \cdot 19$ to $3 \cdot 71)$ and 3 were below the tenth centile for their gestational age.

Blood samples were collected at the time of delivery from a maternal antecubital vein, and from the umbilical vein and artery. The latter were obtained from a segment of the umbilical cord which had been isolated by double clamps at the earliest opportunity.

Two hours after delivery a further blood sample was taken from 30 of the normal infants who had had a vaginal delivery and also from their mothers. The infant blood sample was taken from a peripheral vein (usually an antecubital vein) and preceded the first feed. Permission was obtained from the mother to perform the venepuncture.

The blood for glucagon assay $(1 \mathrm{ml})$ was immediately placed in a chilled heparinized tube containing 1000 KIU (kallikrein inhibitor units) aprotinin. The plasma was separated and frozen within 15 minutes of collection. True glucose was measured by a glucose oxidase method after deproteinization (Marks, 1959).

An antiserum was raised in a New Zealand white rabbit to Novo porcine pancreatic glucagon coupled to serum albumin by carbodi-imide condensation (Assan et al., 1965). The initial and boosting doses contained $200 \mu \mathrm{g}$ of glucagon each and were given at 3-monthly intervals by multiple subcutaneous injections in complete Freund adjuvant. Maximum avidity and titre were reached after 1 year. The antiserum was found to react strongly with pancreatic glucagon but weakly with extracts of human small bowel mucosa known to contain enteroglucagon. The degree of cross-reaction was negligible at the sensitive end of the standard curve and became significant only when large and unphysiological amounts of enteroglucagon were added. The assay was performed in $100 \mu l$ total volume containing $40 \%$ plasma and 100 units aprotinin in duplicate tubes. The porcine pancreatic glucagon standards (Novo) contained an equivalent amount of timeexpired blood bank plasma which has been found to be glucagon free. The assay was incubated at $4^{\circ} \mathrm{C}$ for 5 days. The antibody-bound radioactive glucagon was separated from free radioactive glucagon by addition of $10 \mathrm{mg}$ charcoal as a $1 \mathrm{ml}$ suspension followed by rapid centrifugation and separation of the supernatant. When $4.5 \mathrm{pg}$ of radioactive glucagon label (specific activity $320 \mu \mathrm{Ci} / \mathrm{mg}$ ) was added, a $10 \%$ change in percentage label bound to antibody was produced by plasma containing $80 \mathrm{pg}$ glucagon per $\mathrm{ml}$. Thus the assay could routinely detect changes of $25 \mathrm{pg} / \mathrm{ml}$ with $95 \%$ confidence.

\section{Results}

At delivery the level of plasma glucagon in the normal infants was greater than in their mothers, but this difference was not significant (Table). The umbilical arteriovenous difference was also not significant, and the infants delivered by caesarean section did not differ from those having a vaginal delivery. The glucagon levels were significantly higher in infants with fetal distress than either their mothers $(P<0.01)$ or the normal infants $(P<0.01)$. The mean birthweight was less in the infants with fetal distress, but birthweight alone does not influence cord levels of glucagon in infants of equivalent gestation (Bloom and Johnston, 1972).

TABLE

Infant and maternal plasma glucagon and blood glucose levels

\begin{tabular}{|c|c|c|c|c|c|c|c|}
\hline & \multirow{3}{*}{$\begin{array}{l}\text { Mode of } \\
\text { delivery }\end{array}$} & \multicolumn{4}{|c|}{ Infant } & \multirow{2}{*}{\multicolumn{2}{|c|}{$\frac{\text { Mother }}{\text { Peripheral vein }}$}} \\
\hline & & \multicolumn{2}{|c|}{ Umbilical artery } & \multicolumn{2}{|c|}{ Umbilical vein } & & \\
\hline & & $\underset{(\mathrm{pg} / \mathrm{ml})}{\text { Glucagon }}$ & $\begin{array}{c}\text { Glucose } \\
(\mathrm{mg} / 100 \mathrm{ml})\end{array}$ & $\begin{array}{c}\text { Glucagon } \\
(\mathrm{pg} / \mathrm{ml})\end{array}$ & $\begin{array}{c}\text { Glucose } \\
(\mathrm{mg} / 100 \mathrm{ml})\end{array}$ & $\begin{array}{c}\text { Glucagon } \\
(\mathrm{pg} / \mathrm{ml})\end{array}$ & $\begin{array}{c}\text { Glucose } \\
(\mathrm{mg} / 100 \mathrm{ml})\end{array}$ \\
\hline Normal infants & $\begin{array}{l}\text { Vaginal } \\
\text { Caesarean } \\
\text { Vaginal } \\
\text { Caesarean }\end{array}$ & $\begin{array}{c}138 \\
\pm 14(30) \\
142 \\
\pm 21(10) \\
252 \\
\pm 33(5) \\
254 \\
\pm 31(9)\end{array}$ & $\begin{array}{c}62 \\
\pm 4(30) \\
67 \\
\pm 5(10) \\
60 \\
\pm 4(5) \\
73 \\
\pm 4(9)\end{array}$ & $\begin{array}{c}140 \\
\pm 12(44) \\
130 \\
\pm 16(12) \\
239 \\
\pm 27(8) \\
248 \\
\pm 31(12)\end{array}$ & $\begin{array}{c}76 \\
\pm 3(44) \\
81 \\
\pm 5(12) \\
68 \\
\pm 4(8) \\
82 \\
\pm 7(12)\end{array}$ & $\begin{aligned} & 122 \\
& \pm 13(44) \\
& 126 \\
& \pm 17(12) \\
& 131 \\
& \pm 10(8) \\
& 132 \\
& \pm 13(12)\end{aligned}$ & $\begin{array}{c}98 \\
\pm 4(44) \\
105 \\
\pm 4(12) \\
93 \\
\pm 4(8) \\
106 \\
\pm 3(12)\end{array}$ \\
\hline Normal infants $2 \mathrm{hr}$ after birth & Vaginal & & & Periph & ral vein & & \\
\hline $2 \mathrm{hr}$ increment or decrement & & & & $\begin{array}{l}188 \\
\pm 14(30) \\
+51 \\
\pm 8(30)\end{array}$ & $\begin{array}{c}58 \\
\pm 2(30) \\
-23 \\
\pm 5(30)\end{array}$ & $\begin{array}{c}83 \\
\pm 11(30) \\
-38 \\
\pm 6(30)\end{array}$ & $\begin{array}{c}87 \\
\pm 4(30) \\
-14 \\
\pm 3(30)\end{array}$ \\
\hline
\end{tabular}

Note: Values given are with SEM and the number of subjects in brackets. The 2-hour increment or decrement compares the level at birth in infants' umbilical vein, or maternal peripheral vein, with the level 2 hours after birth. 
In the 2 hours after delivery the difference in the glucagon level between the mothers and infants in the normal group became highly significant. The former showed a fall of $38 \pm 6 \mathrm{pg} / \mathrm{ml}(\mathbf{P}<0.05)$ whereas the latter had a rise of $51 \pm 8 \mathrm{pg} / \mathrm{ml}$ $(P<0.01)$. The rise in glucagon in the infants occurred during a period of falling blood glucose. The mothers also had a fall in blood glucose probably related to discontinuation of intravenous dextrose. There was thus a rise in maternal plasma glucagon during the strenuous phase of labour. This has been more clearly defined by serial measurements in several mothers throughout labour (D. I. Johnston, S. R. Bloom, and K. R. Greene, unpublished observations, 1972).

\section{Discussion}

It is apparent from our data that the level of pancreatic glucagon in the human neonate is low and the rise 2 hours after birth relatively small. A highly sensitive assay, using small plasma volumes, was required for these measurements and that is why there are few data in the literature on neonatal glucagon levels. Degradation of plasma glucagon can occur (Mirsky, Perisutti, and Davis, 1959) and may be very rapid, particularly if red cell lysis has caused release of proteolytic enzymes and other substances (Steinke, Gries, and Driscoll, 1967). All samples were therefore protected by addition of the proteolytic enzyme inhibitor aprotinin (Unger et al., 1967) and rapid freezing. The presence of plasma alters antibody binding (Heding, 1971), and therefore the glucagon standards contained glucagon-free plasma in the same proportion as the unknowns. The crossreaction of enteroglucagon in this assay is minimal. A few patients' samples were assayed in duplicate with Dr. Unger's antiserum $30 \mathrm{~K}$ which is reported to be highly specific for pancreatic glucagon (Muller, Faloona, and Unger, 1971), and nearly identical glucagon changes were detected.

In our study the absence of significant differences between umbilical artery and vein levels (Table) suggests that the placenta plays little part in fetal glucagon metabolism. We have previously shown that there is no transfer of natural glucagon across the human placenta at term even when the gradient is extremely great (Johnston et al., 1972). The finding of nearly identical levels of glucagon in mother and fetus is therefore probably explained by similar levels of metabolites and also by the fact that both are under some stress.

There are few other reports of the measurement of plasma pancreatic glucagon levels in the human neonate and none include the period of birth and first few hours after. Fekete et al. (1972) catheterized the umbilical vein of normal and premature infants and then exposed them to cold stress. They report a mean level of $390 \mathrm{pg}$ glucagon $/ \mathrm{ml}$ plasma in the premature infant and $349 \mathrm{pg}$ glucagon $/ \mathrm{ml}$ plasma in the term infant. Cold stress did not significantly alter these values. This study can be criticized on two points of methodology. Firstly, the infants were studied 4 to 6 hours after a meal when plasma enteroglucagon may have been raised and thus been detected with their antibody which was said to cross-react weakly with this material; and secondly, no proteolytic enzyme inhibitor was added to protect the glucagon from plasma degradation.

In a study of infants with hyperbilirubinaemia (Milner et al., 1972b; Milner, Fekete, and Assan, 1972a) requiring exchange transfusion, high plasma glucagon levels were found. These were not suppressible with glucose and no information was given on the effects of raised bilirubin levels on the assay. No proteolytic enzyme inhibitor was added to the samples. Luyckx et al., (1972) have reported that human portal plasma glucagon values between the 6th and 24th hours of life range from 290 to $4800 \mathrm{pg} / \mathrm{ml}$, tend to rise towards the 24th hour, and are not suppressable by glucose. The only published studies of the glucagon changes in the first 2 hours of life in normal animals are by Girard, Bal, and Assan (1971) in the rat. They found plasma glucagon rises as great as $700 \mathrm{pg} / \mathrm{ml}$, which are of a different order of magnitude from the results in this paper. However, glucagon in the rat may have a more important role in inducing gluconeogenic enzymes (Philippidis and Ballard, 1970), whereas these rate-limiting steps are developed at an earlier stage in human gestation (Räihä and Lindros, 1969).

The ability of young mammals to withstand anoxia is related to their cardiac and hepatic glycogen reserves (Mott, 1961). The term human fetus, when hypoxic, is capable of raising plasma glucose and of accelerating the generation of lactic acid. In their study of normal and hypoxic fetuses at delivery, Stembera and Hodr (1966) measured the plasma glucose gradients between the maternal peripheral vein and the umbilical vein, and also between the umbilical vein and artery. They reported that the former was not significantly affected, but that the latter was reduced and even reversed with increasing degrees of hypoxia. Our study also shows this reduction of the umbilical vein-artery glucose gradient in the stressed fetus. It is not possible to quantitate hepatic glucose release in vivo, but 
these data suggest that it may be occurring to a significant degree. The much higher glucagon levels found in the anoxic infants suggest that glucagon may be partly responsible for this increased glucose release.

The measurement for the first time of human plasma glucagon at birth has shown the levels to be very similar to those in the human adult. There was a small rise in plasma glucagon occurring together with a fall in blood glucose over the 2 hours after birth. However, there was a much greater glucagon rise associated with the stress of birth anoxia when the blood glucose was normal. This suggests that the blood glucose level may not be the main determinant of neonatal glucagon release. In calves the $\alpha$-cell is relatively unresponsive to hypoglycaemia in the first 24 hours of life. The calf $\alpha$-cell has been shown to respond rapidly to splanchnic nerve stimulation (Bloom, Vaughan, and Edwards, 1973). External stress, in the form of pain or fear, has been found to cause large and very rapid glucagon rise in the baboon, and a nervous mechanism of release was postulated (Bloom et al., 1973). It is at least possible that the raised glucagon found in infants with fetal distress is also mediated by the nervous system.

We are grateful to Professor S. G. Clayton and the staff of the Obstetric Unit for their assistance; and to Professor C. E. Stroud and Drs. H. Gamsu and J. D. N. Nabarro for their advice and encouragement.

D.I.J. is on a Maws Research Fellowship and S.R.B. is in receipt of financial assistance from the British Diabetic Association.

\section{REFERENCES}

Assan, R., Rosselin, G., Drouet, J., Dolais, J., and Tchobroutsky, G. (1965). Glucagon antibodies. Lancet, 2, 590.

Beard, R. W., Brudenell, J. M., Feroze, R. M., and Clayton, S.G. (1971). Intensive care of the high-risk fetus in labour. Fournal of Obstetrics and Gynaecology of the British Commonwealth. 78, 882.

Bloom, S. R., Daniel, P. M., Johnston, D. I., Ogawa, O., and Pratt, O. E. (1973). Release of glucagon induced by stress. Ouarterly fournal of Experimental Physiology, 58, 99.

Bloom, S. R., and Johnston, D. I. (1972). Failure of glucagon release in infants of diabetic mothers. British Medical fournal, $4,453$.

Bloom, S. R., Vaughan, N. J. A., and Edwards, A. V. (1973). Pancreatic glucagon levels in the calf. 8th Annual Meeting of the European Association for the Study of Diabetes, Madrid. Diabetologia. (In the press.)

Fekete, M., Milner, R. D. G., Soltész, G., Assan, R., and Mestyán, J. (1972). Plasma glucagon, thyrotropin, growth hormone and insulin response to cold exposure in the human newborn. Acta Paediatrica Scandinavica, 61, 435.

Gennser, G., and Nilsson, E. (1971). Plasma glucose concentration in human midterm fetus. Biology of the Neonate, 17, 135.

Girard, J., Bal, D., and Assan, R. (1971). Rat plasma glucagon during the perinatal period. (Abst.) Diabetologia, 7, 481.

Heding, L. G. (1971). Radioimmunological determination of pancreatic and gut glucagon in plasma. Diabetologia, 7, 10.

Johnston, D. I., Bloom, S. R., Greene, K. R., and Beard, R. W. (1972). Failure of the human placenta to transfer pancreatic glucagon. Biology of the Neonate, 21, 375.

Luyckx, A. S., Massi-Benedetti, F., Falorni, A., and Lefebvre, P. J. (1972). Presence of pancreatic glucagon in the portal plasma of human neonates. Differences in insulin and glucagon responses to glucose between normal infants and infants from diabetic mothers. Diabetologia, 8, 296.

Marks, V. (1959). An improved glucose-oxidase method for determining blood, C.S.F. and urine glucose levels. Clinica Chimica Acta, 4, 395.

Milner, R. D. G., Fekete, M., and Assan, R. (1972a). Glucagon, insulin, and growth hormone response to exchange transfusion in premature and term infants. Archives of Disease in Childhood, 47, 186.

Milner, R. D. G., Fekete, M., Assan, R., and Hodge, J .S. (1972b). Effect of glucose on plasma glucagon, growth hormone, and insulin in exchange transfusion. Archives of Disease in Childhood, 47, 179.

Mirsky, I. A., Perisutti, G., and Davis, N. C. (1959). The destruction of glucagon, adrenocorticotropin and somatotropin by human blood plasma. Fournal of Clinical Investigation, 38, 14.

Mott, J. C. (1961). The ability of young mammals to withstand total oxygen lack. British Medical Bulletin, 17, 144.

Muller, W. A., Faloona, G. R., and Unger, R. H. (1971). The effect of experimental insulin deficiency on glucagon secretion. Fournal of Clinical Investigation, 50, 1992.

Park, C. R., and Exton, J. H. (1972). Glucagon and the metabolism of glucose. In Glucagon, p. 77. Ed. by P. J. Lefebvre and R. H. Unger. Pergamon Press, Oxford.

Philippidis, H., and Ballard, F. J. (1970). The development of gluconeogenesis in rat liver-effects of glucagon and ether. Biochemical fournal, 120, 385.

Răihă, N. C. R., and Lindros, K. O. (1969). Development of some enzymes involved in gluconeogenesis in human liver. Annales Medicinae Experimentalis et Biologiae Fenniae, 47, 146.

Shelley, H. J. (1961). Glycogen reserves and their changes at birth and in anoxia. British Medical Bulletin, 17, 137.

Shelley, H. J., and Neligan, G. A. (1966). Neonatal hypoglycaemia. British Medical Bulletin, 22, 34.

Steinke, J., Gries, F. A., and Driscoll, S. G. (1967). In vitro studies of insulin inactivation with reference to erythroblastosis fetalis. Blood, 30, 359 .

Stembera, Z. K., and Hodr, J. (1966). Mutual relationships between the levels of glucose, pyruvic acid and lactic acid in the blood of the mother and of both umbilical vessels in hypoxic fetuses. Biology of the Neonate, 10, 303.

Tanner, J. M., and Thomson, A. M. (1970). Standards for birthweight at gestation periods 32 to 42 weeks, allowing for maternal height and weight. Archives of Disease in Childhood, 45, 566.

Unger, R. H., Ketterer, H., Dupré, J., and Eisentraut, A. M. (1967). The effects of secretin, pancreozymin and gastrin on insulin and glucagon secretion in anaesthetized dogs. fournal of Clinical Investigation, 46, 630.

Correspondence to Dr. S. R. Bloom, Institute of Clinical Research, Middlesex Hospital, London W1. 